\title{
KINERJA GURU AGAMA HINDU BERBASIS BUDAYA RELIGIUS MORAL
}

\author{
Oleh: \\ I Nyoman Sueca \\ Dosen pada Institut Hindu Dharma Negeri Denpasar
}

\begin{abstract}
Religious culture is a movement carried out by religion, from the process of human interaction with a doctrine that has been believed by society is a performance of religious teachers to instill budhi pekerti to learners, so that cultural relations with religion is the integrity of a person or group.Given the religious school culture held by principals, teachers, administrative staff, and students will bring a dominant value supported by the school.School culture consists of values, beliefs, knowledge, and traditions, ways of thinking, and behavior that are all different from other social institutions. School culture is a very important component to promote a positive school and can pay attention to mothers fathers, teachers, and other students. School activities are still often done by the school as a form of moral religious culture such as; culture greetings, wall magazines, interactive dialogue, siplin culture, hard work culture, creative culture, and independent culture.
\end{abstract}

Keywords: Performance of religion-based religious teachers.

\section{PENDAHULUAN}

Sekolah salah satu wadah untuk menciptakan manusia yang berpendidikan tanpa melihat latar belakang budaya, tingkat sosial, dan tingkat ekonomi siswa. Dengan adanya sekolah diharapkan dapat diterima oleh semua golongan yang berkepentingan terhadap lembaga tersebut. Lembaga pendidikan seperti sekolah dibentuk dengan tujuan untuk menciptakan sumber daya manusia (SDM) yang berkualitas. Tentu hal ini bukan pekerjaan yang mudah dan tidak memerhatikan aturan-aturan pelaksanaannya. Sekolah sebagai sebuah lembaga yang bergerak dalam bidang pengembangan SDM (sumber daya manusia) pasti dalam menjalankan kenerja kelembagaanya harus mempertimbangkan banyak hal, antara lain tujuan sekolah, kebijakan yang lahir dalam system sekolah, perencanaan SDM (sumeber daya amanusia) dalam suatu sekolah, prosedur kerja pengembangan SDM, dan proses administrasi personel di sekolah tersebut.

Sistem sekolah merupakan suatu tujuan yang para anggotanya mencoba melalui usaha bersama untuk mencapai tujuan. Hal ini menjadi jelas bahwa strategi jangka panjang dan administrasi personal membantu sistem sekolah untuk menarik, mengunakan, dan mengembangkan jenis-jenis SDM yang dibutuhkan untuk meraih keseluruhan tujuannya.

Dalam keseluruhan kegiatan pendidikan di jalur sekolah guru memegang posisi paling strategis yang berada di barisan paling depan, terutama dalam berinteraksi dengan peserta didik di kelas atau di luar kelas. 
Oleh karena itu dalam reformasi pendidikan guru menjadi titik awal dalam penataannya. Terutama menyangkut hak-hak asasi guru sebagai pribadi, pemangku profesi guru, anggota masyarakat, dan warga negara perlu mendapat prioritas dalam pemberdayaannya. Masyarakat paling terbelakang sampai kepada masyarakat yang paling maju mengakui bahwa guru merupakan satu di antara sekian banyak unsur pembentukan utama calon anggota masyarakat. Namun wujud pengakuan itu berbeda-beda antara masyarkat yang satu dengan masyarakat yang lain. Padahal tugas pendidik sekarang ini hampir sepenuhnya ditumpahkan kepada guru, baik dalam hal mengembangkan aspek kognitif, afektif, maupun psikomotor.

Guru menempati peranan dalam mengelola kegiaan pembelajaran. Peranan kunci ini dapat di emban apabila ia memilki tingkat kemampuan profesional yang tinngi, yang tidak hanya diukur dari kemampuan intlektual, tetapi juga dituntut untuk memiliki keunggulan dalam aspek moral, keimanan, ketakwaan, tanggung jawab, dan keluasan wawasan kependidikan (umum dan agama) dalam mengelola kegiatan pembelajaran di dalam kelas (Kemenag RI, 2001:21-24).

Guru harus mampu menunjukkan kinerja maksimal di dalam menjalankan tugas dan fungsinya sebagai pendidik, pengajar, dan pelatih. Akan tetapi jika sebagian guru yang belum menunjukkan kinerja baik, akan berpengaruh terhadap kinerja guru secara makro. Pada kenyataannya, perlu adanya budaya sekolah yang mantap dalam mengelola guru, salah satunya adalah budaya religius sekolah. Dengan adanya budaya religius sekolah yang dipegang oleh kepala sekolah, guru, staf administrasi, dan siswa akan membawa sebuah nilai yang dominan yang didukung oleh sekolah.

Budaya sekolah terdiri dari pada nilainilai, kepercayaan, pengetahuan, dan tradisi, cara berfikir, dan tingkah laku yang semuanya berbeda dari pada institusi-institusi sosial lain. Menurut Deal (dalam Daryanto, 2015: 5-6) budaya sekolah adalah keyakinan dan nilainilai milik bersama yang menjadi perangkat kuat kebersamaan mereka sebagai warga suatu masyarakat. Jika diterapkan di sekolah, sekolah dapat saja memilki sejumlah kultur dengan satu kultur dan kultur lain sebagai subordinasi. Sedangkan menurut Sharifah (2000), budaya sekolah adalah sebagai cara hidup sekolah yang meliputi segala perbuatan luar sekolah dan di dalam ruangan yang mencerminkan nilai, kepercayaan, dan norma yang bekerjasama sesama warganya ada yang telah diwarisi turun temurun ada yang telah dibentuk oleh warga sekolah itu sendiri.

Segenap warga sekolah perlu memilki wawasan bahwa ada unsur kultur yang bersifat positif, negatif, dan ada yang netral, dalam kaitannya dengan visi dan misi sekolah. Contoh, kalau sekolah memilki visi dan misi terkait dengan mengangkat persoalan mutu, moral, dan multikultur, sekolah harus dapat mengenali aspek-aspek kultur yang cocok dan menguntungkan bagi institusi demi kecerdasan anak bangsa.

Budaya sekolah merupakan komponen yang sangat penting untuk memajukan sekolah yaitu dengan memastikan budaya sekolah yang bersifat positif dan dapat memberikan perhatian kepada ibu bapak, guru, dan siswa lainnya. Kegiatan sekolah yang masih sering dilakukan sekolah sebagai wujud budaya religius moral seperti; 
1. Budaya salam, dimana setiap kali bertemu (guru, siswa, dan orang tua) saling mengucapkan salam "Om Suwastyastu" dan saling berjabatan tangan.

2. Majalah sekolah, majalah dinding sekolah yang dibuat oleh siswa untuk melatih jurnalistiknya.

3. Dialog interaktif dengan para pakar di bidangnya, mulai dari masalah yang kuno sampai teknologi terbaru.

4. Lintas juang untuk mendidik siswa menjadi calon pengurus Osis.

5. Studi kepemimpinan siswa untuk melatih kepemimpinan siswa menjalankan organisasi.

6. Budaya disiplin dimana siswa tidak diperkenankan masuk kelas, bila terlambat dan melakukan pelanggaran tatatertib sekolah.

7. Budaya kerja keras, cerdas, dan iklas adalah siswa dilatih menyelesaikan tugas-tugasnya dengan cepat, tepat waktu, dan berharap mendapatkan hasil dari Tuhan (Ida Sang Hyang Widhi Wasa).

8. Budaya kreatif yaitu melatih siswa menciptakan inovasi sesuai bakat dan minatnya.

9. Budaya mandiri dan bertanggung jawab yaitu melatih siswa untuk bekerja sendiri tanpa bantuan orang lain dan bertanggung jawab penuh terhadap tugas yang diberikasn guru.

Secara realitas bahwa kinerja guru agama Hindu berbasis budaya religius moral, belum mampu menunjukan hasil yang signifikan. Hal ini dapat dilihat di berbagai daerah yang ada di Indonesia secara umum, dan khusunya beberapa sekolah yang ada di Bali, masih terjadinya tawuran antar siswa, terjadinya pranikah, dan beberapa anak muda masih terjerat narkoba. Harapan penulis, untuk memperkuat kinerja guru agama dalam menanamkan budaya religius moral pada pesert didik, semua guru dan staf administrasi saling bersinergi, sehinga pengawasan peserta didik dapat dilaksanakan secara optimal.

Bagi kepala yang baru bertugas di suatu sekolah, mereka harus peka terhadap budaya sekolah yang telah ada. Kepala sekolah yang baru, akan mengalami kesulitan untuk menjalankan tugas jika dia tidak memahami budaya sekolah itu. Dengan demikian kepala sekolah baru, harus memahami dan mampu beradaptasi terhadap lingkungan sekolah sebagai tempat kerja yang baru.

\section{PEMBAHASAN}

Membertahakan budaya religius sekolah merupakan suatu pekerjaan, bukan hal yang mudah, namun merupakan pekerjaan yang mesti dikerjakan oleh seluruh warga sekolah dan masyarakat sekitarnya. Kebertahan budaya sekolah, guru merupakan kunci utama, dan guru harus mampu menunjukkan kinerja maksimal di dalam menjalankan tugas dan fungsinya sebagai pendidik, pengajar, dan pelatih. Budaya sekolah bukan merupakan fenomena baru, melainkan penggalian kembali hal-hal penting tentang budaya sebagai faktor pertimbangan terbaik di sekolah. Peranan kepala sekolah didalam penciptaan dan pelanjutan suatu budaya sekolah adalah mengembangkan fokus berdasarkan perbuatn-perbuatan kepala sekolah di masa yang akan datang melalui 
sesuatu yang penting dan aktivitas-aktivitas sebagai manejerial.

Budaya sebagai "cara kita melakukan sesuatu disekitar itu" justru merupakan titik awalnya. Kita melakukan sesuatu di sekolah karena kita mempunyai nilai-nilai dan keyakinan khusus tentang apa yang semestinya dilakukan di sekolah. Disitu ditemukan dasardasar budaya yang tidak dapat diperhitungkan, tetapi banyak ditemukan manifestasi budaya berupa sesuatu yang sudah jelas, seperti bentuk-bentuk yang kita gunakan berupa tingkah laku yang kita miliki, dan pembangunan fasilitas-fasilitas lain maupun simbol-simbol yang dibangun secara bersama.

Kinerja guru agama Hindu yang berbasis pada sebuah budaya religius merupakan gerakkan yang dilakukan oleh agama dari proses interaksi manusia dengan sebuah ajaran yang telah diyakini, sehingga hubungan budaya dengan agama merupakan integritas seseorang atau kelompok. Menurut Sumadi dikutip Radiansyah (dalam, Kompri, 2015: 196) menyatakan agama berasal dari bahasa Sanskerta dari kata $a$ berarti tidak dan gama berarti kacau. Kedua kata itu jika dihubungkan berarti sesuatu yang tidak kacau. Jadi fungsi agama pengertian ini ialah memelihara integritas seseorang atau kelompok orang agar hubungannya dengan Tuhan, sesama, dan alam sekitarnya tidak kacau. Oleh karena itu menurut Hinduisme, agama sebagai kata benda berfungsi memelihara integritas seseorang atau kelompok agar hubungan dengan realitas tertinggi sesama manusia , dan alam sekitarnya tidak kacau. Ketidak kacauan ini disebabkan oleh penerapan peraturan agama tentang moralitas, nilai-nilai kehidupan yang perlu dipegang dimaknai dan diberlakukan.
Pengertian ini juga terdapat dalam kata religion (bahasa Ingris) yang berasal dari kata religio (bahsa Latin) yang berakar dari kata religare yang berarti mengikat. Dalam pengertian religio termuat peraturan tetang kebhaktian, bagaimana manusia mengutuhkan hubungannya dengan realitas tertinggi (vertikal) dalam penyembahan dan hubungan secara horizontal.

Menurut Abbas (dalam, Kompri, 2015: 197) agama muncul sebagai jawaban manusia atas penampakan tertinggi secara misterius yang menakutkan tetapi sekaligus memesonakan. Dalam pertemuan itu manusia tidak berdiam diri, ia harus terdesak secara batiniah untuk merespons. Dalam kaitan ini, ada juga yang mengartikan religare dalam arti melihat kembali ke belakang pada hal-hal yang berkaitan dengan perbuatan Tuhan yang harus diresposnya untuk menjadi pedoman dalam hidupnya. Komarudin Hidayat (Kompri, 2015: 197) memandang agama sebagai kata kerja yaitu, sebagai sikap keberagamaan atau kesolehan hidup, berdasarkan nilai-nilai ketuhanan, sedangkan sebagain kata benda bahwa agama sebagai himpunan doktrin. Walaupun kedua pandangan berbeda, sebab ada yang memandangsebagai kata benda dan sebagai kata kerja, keduanya sama-sama memandang sebagai suatu system keyakinan untuk mendapatkan keselamatan di alam sekala dan di alam niskala. Dengan agama orang akan mencapai realitas yang tertinggi. Brahman dalam Hinduisme, Bodhisatwa dalam Bodddhisme Mahayana, sebagai Yehweh yang diterjemahkan "Tuhan Allah" dalam agama Kristen, dan Allah subhana wata'ala dalam Islam.

Budaya menurut Koentjaraningrat (dalam Radiansyah, 2011) adalah keseluruhan 
sistem, gagasan, tindakan, dan hasil kerja manusia dalam rangka kehidupan masyarakat yang dijadikan milik manusia dengan belajar. Jadi budaya diperoleh dengan belajar. Tindakan-tindakan yang dipelajari, antara lain cara makan, cara minum, berpakian, berbicara, bertani, dan berrelasi dalam masyarakat merupakan budaya. Namum kebudayaan tidak hanya terdapat dalam soal teknis, tetapi juga dalam gagasan yang terdapat dalam pikiran yang kemudian terwujudd alam seni, tatanan masyarakat, etos kerja, dan pandangan hidup.

Pengaruh agama terhadap budaya manusia menurut Radiansyah (dalam Kompri, 2015:198) yang immaterial bahwa motologis hubungan kolektif tergantung pada pemikiran Tuhan. Interaksi social dan keagamaan berpola bagaimana mereka memikirkan Tuhan, menhayati dan membayangkan Tuhan. Lebih tegas dikatanak Geertz (dalam Kompri, 2015:198) bahwa wahyu membentuk suatu struktur psikologis dalam benak manusia yang membentuk pandangan hidupnya, yang menjadi serana individu atau kelompok individu yang mengarah tingkah laku mereka. Namun wahyu tidak menghasilkan budaya immaterial, tetapi dalam bentuk seni suara, ukiran, dan bangunan. Budaya agama tersebut akan terus tumbuh dan berkembang sejalan dengan perkembangan kesejarahan dalam kondisi objektif dari kehidupan penganutnya. Namun hal pokok bagi semua agama ialah agama berfungsi sebagai alat pengatur sekaligus membudayakan dalam arti mengungkapkan apa yang mereka percaya dalam bentuk-bentuk, budaya, yaitu dalam bentuk etnis, seni, bangunan, struktur masyarakat, adat istiadat dan lain-lainnya. Jadi ada pluralisme budaya berdasarkan kreteria agama, hal ini terjadi karena manusia sebagai homoreligiosus merupakan isan yang berbudi daya dan dapat berekriasi dalam kebebasan menciptakan pelbagai objek realitas dan tata nilai baru berdasarkan inspirasi agama.

Jika diteliti budaya di Indonesia, diperoleh bahwa budaya terdiri atas lima lapisan. Lapisan itu diwakili oleh budaya agama pribumi, Hindu, Budha, Islam, dan Kristen, sebagai berikut.

1. Lapisan pertama ialah agama pribumi yang memiliki ritus-ritus yang berkaitan dengan penyembahan roh nenk moyang yang telah tiada atau lebih setingkat, yaitu dewa-dewa, seperti Sombaon di Tanah Batak, agama merapu di Sumba, dan Kaharingan di Kalimantan Tengah.

2. Lapisan kedua ialah Hinduisme, yang telah meninggalkan peradaban yang menekankan pembebasan rohani agar Atman bersatu dengan Brahman, maka dari itu ada solidaritas mencari pembebasan bersama, solidaritas itu diungkapkan dalam kalimat Tat Twam Asi.

3. Lapisan ketiga ialah agama Buddha, yang telah mewarisi nilainilai yang menjauhi ketamakan dan keserakahan

4. Lapisan kempat ialah agama Islam yang telah menyumbangkan kepekaan terhadap tata tertib kehidupan melalui syari'ah, ketaatan melakukan shalat dalam lima waktu.

5. Lapisan kelima ialah agama Kristen, baik Katholik amupun Protestan. Agama ini menekankan 
nilai kasih dalam hubungan antarmanusia.

Penanaman kinerja guru agama Hindu yang berbasis pada sebuah budaya religius merupakan gerakkan yang dilakukan oleh agama dari proses interaksi manusia dengan sebuah ajaran yang telah diyakini, sehingga hubungan budaya dengan agama merupakan integritas seseorang atau kelompok. Penanaman kinerja pimpinan sekolah berbasis budaya religius terhadap warga sekolahnya dapat dilakukan sebagai berikut.

\section{Hakekat Budaya Religius}

Menurut Koentjaraningrat dikutip Rurohman (2009: 36), budaya religius adalah keseluruhan sistem gagasan, tindakan, dan hasil karya manusia dalam rangka kehidupan masyarakat yang dijadikan milik manusia dengan proses belajar. Budaya itu dapat berwujud bahasa, sistem peralatan hidup dan teknologi, sistem pencaharian hidup, sistem relegi, dan kesenian.

Agama (relegi) berdasarkan sudut pandang kebahasaan bahasa Indonesia berasal dari bahasa Sanskerta yang artinya tidak kacau. Agama merupakan salah satu aspek dalam kehidupan sosial dan bagian dari sistem sosial suatu masyarakat (Kahmad, 2002; 13). Agama juga bisa dilihat sebagai unsur kehidupan suatu masyarakat selain unsur-unsur lain, seperti; kesenian, bahasa, sistem mata pencaharian, sistem peralatan, dan sistem organisasi sosial.

Budaya religius di sekolah merupakan sekumpulan nilai agama yang disepakati bersama dalam organisasi sekolah yang melandasi prilaku, tradisi, kebiasan, dan symbol-simbol yang dipraktikkan oleh masyarakat termasuk disekitar sekolah atau warga sekolah. Budaya religius merupakan salah satu metode pendidikan nilai yang komprehensif, karena dalam perwujudannya terdapt inklusi nilai, pemberian teladan, dan penyiapakn generasi muda agar mandiri dengan mengajarkan dan memfasilitasi perbuatan-perbuatan keputusan moral secara bertanggung jawab dan ketrampilan hidup yang lain Zuchdi (Kompri, 2015: 202). Maka dari itu dapat dikatakan mewujudkan budaya religius di sekolah merupakan salah satu upaya untuk menginternalisasikan nilai keagamaan ke dalam diri peserta didik. Selain itu, hal ini menunjkkan fungsi sekolah, sebagai mana diungkapkan Abdul Latif, "sebagai lembaga yang berfungsi mentransmisikan budaya" (Latif, 2005:30).

\section{Kenerja Guru Berbasis Budaya Religius}

Pendidikan merupakan usaha sadar untuk mencerdaskan kehidupan bangsa yang diharapkan mampu memberikan peran aktif dan sumbangan sebagai usaha untuk mengantisipasi dalam menghadapi persaingan global yang semakin ketat. Selain itu, pendidikan diharapkan mampu memberikan kontribusi atau sumbangan secara nyata terhadap pembangunan bangsa Indonesia. Arah, visi, dan misi pendidikan harus mampu menyentuh semua aspek kehidupan di negara ini.

Dalam proses pencapaian pembangunan melalui pendidikan tersebut, secara internal, pendidikan yang bertumpu pada sekolah melakukan persiapan-persiapan dan perbaikan-perbaikan sebagai upaya meningkatkan kinerja tenagan pengajar di sekolah. Kedua komponen itu merupakan komponen yang paling bertanggung jawab dalam proses pembelajaran di sekolah melalui tenaga mengajar. Tenaga pengajar merupakan tenaga lapangan yang mendukung terlaksananya proses pembelajaran dan 
merupakan ujung tombak dalam tertib administrasi disekolah umum. Secara eksternal, pendidkan yang bertumpu di sekolah secara mutlak tidak dapat melakukan fungsifungsi manejerialnya sendiri. Hal ini karena adanya keterbatasan-ketebatasan, baik dari segi manajemen administrasi, maupun pembiayaan. Oleh karena itu, pendidikan yang bertumpu di sekolah-sekolah tersebut harus mampu melakukan terobosan-terobosan.

Peningkatan kinerja guru mengajar merupakan suatu usaha untuk meningkatkan kualitas hasil pendidik. Usaha tersebut dilakukan karena masalah-masalah yang berkaitan dengan tenaga guru dan pegawai di sekolah biasanya meliputi kurang memadainya kualifikasi dan kompetensi tenaga pengajar, rendahnya etos kerja, kurangnya penghrgaan masyarakat terhadap komitmen tenaga pengajar, dan kurangnya penghargaan masyarakat terhadap profesi tenaga guru.

Hindu sangat menghargai dan menghormati orang yang berilmu pengetahuan dan bertugas sebagai pendidik. Dalam ajaran Canakia Nitisastra, BAB III Sloka 9, disebutkan;

\section{Kokilanam svaro rupam \\ Nari rupam pativratam \\ Vidya rupam kurupanam \\ Ksama rupam tapasvinam}

Artinya : Burung tekukur menjadi indah menarik karena suaranya, seorang istri menarik karena kesetiannya kepada suami, orang yang rupanya buruk menjadi menarik karena ilmu pengetahuannya dan karena memiliki sifat maha pengampun pendeta menjadi menarik.

Jadi sesuai dengan arti sloka diatas menunjukkan adalah keberuntungan bagi yang berilmu, bahwa betapa pentingnya pengetahuan dalam kehidupan kita, orang berpengetahuan adalah orang yang kaya, wanita cantik karena pengetahuan. Memerhatikan begitu mulia dan utamanya tugas seorang guru, maka untuk menjaga keunggulan tersebut guru perlu diberi Job description yang tepat dan sesuai dengan keahliannya agar tugas yang diberikan tersebut dapat dilaksanakan dengan maksimal. Sebaliknya, apabila tugas yang diberikan tersebut tidak dapat dilaksanakan dengan maksimal dan apabila tugas yang diberikan (bidang studi) tidak sesuai dengan keahliannya maka sulit diharapkan bisa tercapai tujuan pendidikan yang maksimal.

Dengan demikian untuk mencapai tujuan sesuai dengan keahlian, maka kerjakanlah sesuai dengan dharmanya. Dalam Canakya Nitisastra BAB XIII Sloka 9. disebutkan;

\section{Jivantam mrtavan-manye \\ Dehinam dharma-varjitam \\ Yato dharmena samyukto \\ Dirgha-jivi na samsayah}

Artinya: Orang yang perbuatannya tidak sesuai dengan dharma, sebenarnya ia sudah mati, walaupun masih hidup. Seorang dharmatma yaitu orang yang perbuatannya sepenuhnya sesuai dengan dharma, sebenarnya ia masih hidup, walaupun sudah mati.

Sloka diatas menganjurkan bahwa sebagai manusia bekerja dan bertindak sesuai dengan keadaan, kemampuan, dan keahlian. Oleh karena itu, jika menempatkan seorang guru pada mata pelajaran yang bukan keahliannya atau profesinya akan menyulitkan pekerjaan guru itu sendiri untuk mengembangkan kariernya yang berakibat akan menurunya kualitas siswa.

Professional dalam pendidikan adalah seperangkat fungsi dan tugas dalam lapangan pendidikan berdasarkan keahlian yang diperoleh melalui pendidikan dan latihan khusus dalam bidang pekerjaan yang mampu mengembangkan kekayaan itu secara ilmiah selain mampu menekuni bidang profesi selama hidupnya. Mereka adalahh para guru yang professional yang memiliki kompetensi keguruan berkaitan dengan pendidikan dan pelatihan di lembaga pendidikan guru dalam 
jangka waktu tetentu, Arifin (dalam Kompri, 2015: 210).

Profesionalisme memilki berbagai faktor kemampuan khususnya yang meliputi komponen intlektual dan komitmen yang kuat terhadap pekerjuaan yang berbasis pada kemampuan yang khusus tersebut. Selain itu harus memiliki tanggung jawab sesuai dengan kemampuan khusus tersebut dan memberikan servis yang baik kepada pelanggan. Menurut Amstrong (dalam Kompri, 2015: 210), professional adalah tingkat kemahiran atau keahlian yang disyaratkan (dituntut) untuk dapat melakukan suatu pekerjaan (jabatan) secara efektif dan efisien dengan tingkat keahlian yang tingi dalam mencapai tujuan pekerjaan (jabatan) tersebut. Kemampuan melakssanakan tugas-tugas yang menjadi tanggung jawab guru merupakan sebagian dari kompetensi professional tenaga pengajar yakni tanggung jawab dalam;

1. Pengajaran;

2. Bimbingan belajar;

3. Pengembangan kurikulum;

4. Pengembangan profesi;

5. Pengembangan kerjasama dengan masyarakat.

Kompetensi guru sebagai tenaga akademik erat hubungannya dengan prestasi akademik yang dicapai siswa, James E. Weigan yang dikutif oleh Nana Sudjana (2000: 70) mengemukakan ada tiga faktor diluar kemampuan siswa yang mempengaruhi prestasi belajar, yakni sebagai berikut.

1. Kondisi yang diperlukan untuk belajar.

2. Kompetensi tenaga pengajar.

3. Interkasi personal antara tenaga pengajar dan siswa dalam proses belajar mengajar.

Demikian pentingnya dan agungnya orang yang meilki pengetahuan dan dikaitkan dengan profesionalisme guru sebagai pendidik yang akan mentransper pengetahuan kepada anak didk pastinya akan diberikan kedudukan tinggi di sisi Tuhan. Kompetensi guru dapat diartikan sebagai kemampuan yang dimiliki oleh guru, yakni kemampuan guru yang menyangkut pengetahuan tentang belajar dan tingkah laku manusia, misalkan mengetahui dan menguasai bidang studi yang dibinanya, mempunayai sikap yang tepat tentang diri sendiri, sekolah. Dan teman, dan mempunyai ketrampilan teknik mengajar. Dengan adanya kompetensi diharapkan guru dapat benar-benar meningkatkan dirinya dalam proses pembelajaran.

Perumpamaan kekuatan lingkungan dan budaya yang telah tertuang dalam ajaran suci yaitu "Saracamuccaya", bertemu dengan orang suci, kita harus berbicara masalah spiritual. Sehingga dari pengalaman bergaul dengan orang-orang suci kita akan terpengaruh pada sifatnya, sekalipun kita bukan orang suci. Dan kalau bertemu sama orang-orang jahat, kita harus mampu berbicara kejahatan, walupun kita tidak pernah berbuat jahat, hal itu demi keselamatan, dan terhindar dari orang jahat. Pembiasaan berprilaku religius di sekolah ternyata mampu mengantarkan anak didik untuk berbuat yang sesuai dengan etika. Dampak pembiasaan perilaku religius tersebut berpengaruh terhadap tiga hal yang disebut Tri kaya parisudha, sebagaimana terlihat dalam tabel berikut.

Tabel. 1

Prilaku Religius dalam

Kehidupan Bermasyarakat

\begin{tabular}{|l|l|l|}
\hline NO & $\begin{array}{c}\text { Tri Kaya } \\
\text { Parisudha }\end{array}$ & \multicolumn{1}{|c|}{ Implementasi } \\
\hline 1 & Pikiran & $\begin{array}{l}\text { Peserta didik mulai } \\
\text { berpikir positif (positif } \\
\text { thinking). Peserta didik } \\
\text { mulai } \\
\text { prasangka buruk terhadap } \\
\text { orang lain. Mereka selalu } \\
\text { terbuka dan mau bekerja } \\
\text { sama dengan siapa saja } \\
\text { tanpa rangandang } \\
\text { perbedaan agama, suku, } \\
\text { dan ras. }\end{array}$ \\
\hline
\end{tabular}




\begin{tabular}{|l|l|l|}
\hline 2 & Perkataan & $\begin{array}{l}\text { Prilaku yang sesuai } \\
\text { dengan etika ialah tutur } \\
\text { kata yang sopan, tidak } \\
\text { berbohong terhadap } \\
\text { siapapun, mengucapkan } \\
\text { terimaksih, jika diberi } \\
\text { sesuatu. }\end{array}$ \\
\hline 3 & Perbuatan & $\begin{array}{l}\text { Tingkah laku yang } \\
\text { terbentuk dari prilaku } \\
\text { religius, tentunya tingkah } \\
\text { laku yang benar yang } \\
\text { sesuai dengan etika yaitu; } \\
\text { tidak mencuri, tidak } \\
\text { merampok, suka } \\
\text { menolong orang lain, } \\
\text { empati, hormat, kasih } \\
\text { sayang, dan kebersamaan. }\end{array}$ \\
\hline
\end{tabular}

Sumber Daya Manusia di sekolah sudah terbiasa hidup dalam lingkungan yang penuh dengan kebiasaan religius, kebiasaankebiasaan itupun akan melekat dalam dirinya dan diterapkan dimanapun mereka berada. Begitu juga sikap dalam berucap, berpikir, dan bertingkah laku, akan selalu didasarkan norma agama, moral, dan etika yang berlaku. Jika itu diterapkan pada semua sekolah khususnya bagi para pendidik, niscayaakan terbentuk generassi muda Hindu yang andal, bermoral, dan beretika, Rustantiningsih (dalam Kompri, 2015: 212).

Melalui agama itulah akan muncul sebaik-baiknya perbuatan yang baik maupun tidak baik. Melalui agama diharapkan adanya energi positif yang turut serta membangun peradaban. Dengan demikian, diharapkan religius menjadi sumber rujukan dalam menghampiri globalisasi. Sebagai umat Hindu modalitas itu sudah ada sejak dini, bahkan masih dalam kandungan, hal itu merupakan subha asubha karma, namun apakah modalitas itu ada secara potensial atau actual, itu tergantung pada diri sendiri.

$\begin{array}{ccr}\text { Sekolah sebagai } & \begin{array}{r}\text { agen } \\ \text { budaya } \\ \text { diharapkan berperan }\end{array}\end{array}$

pembudayaan dan tindakan.yang diperankan oleh para pendidik (kepala sekolah, guru, dan pegawai). Maka dari itu kepala sekolah selaku top manejer harus lebih mengedepankan aspek religius yang harus ditanamkan di lembaga yang dikelolanya, terutama bagi bidang pendidik umm maupuan pendidik agama.

\section{Program Peningkatan kinerja Guru Agama Berbasis Budaya Religius}

Peningkatan profesionalisme guru diartikan usaha untuk memperluas pengetahuan, meningkatkan ketrampilan mengajar, dan menumbuhkan sikap professional sehingga para guru menjadi ahli dalam mengelola kegiatan belajar mengajar untuk membelajarkan peserta didik, (Dekdikbud, 1994:12). Tingkah laku, sikap, kepribadian, dan keahlian (kompetensi) guru dipengaruhi tiga aspek yaitu; kognitif, afektif, dan psikomotorik. Jika seorang guru memiliki kapasistas yang seimbang dari ketiga aspek tersebut, secara teori ia dapat menjalankan tugasnya dengan baik dan dapat hidup harmonis dengan lingkungan sekolah, dan dengan dirinya , karena ia mampu mengamati dan merespons permasalahan dengan baik, benar, dan professional. Secara konkret, apabila guru sudah memilki ketiga aspek tersebut baru dapat dikatakan professional, Banjari (dalam Kompri, 2015: 213).

Budaya religius adalah perilaku akhlak kerja yang terjadi karena internalisasi keyakinan nilai kerja yang berasal dari akhlak mulia, baik nilai spiritual-keagmaan IMTAQ, IPTEK, adat istiadat, hukum maupun etika yang ditumbuhkembangkan sebagai gaerah (etos kerja). Adapun program-program yang diterapkan oleh kepala sekolah dalam meningkatkan professional guru berbasis religius sebagai berikut. 
1. Mengembangkan budaya keteladaan dan kedisiplinan

Seluruh civitas akademik di sekolah baik kepala sekolah, wakil kepala sekolah, guru-guru staf mupun siswa harus memilki tiga hal yaitu; a. Competency, menyangkut kemampuan dalam menjalankan tugas-tugas, $b$. Personality, menyangkut integritas, komitmen, dan dedikasi, c. religiosity, menyangkut pengetahuan, kecakapan, dan pengamalan bidang keagamaan. Dengan ketiga hal tersebut guru mampu menjadi model dan mampu mengembangkan keteladanan di hadapan siswa.

2. Membangun komunikasi secara intensif.

Suasana religius sekolah (school religiosity climate) tercermin baik secara fisik, social, maupun kultur. Secara fisik lingkungan sekolah sangat bersih, asri, dan dilengkapi dengan tempat suci berupa Padma sana sebagai tempat melakukan aktifitas religius.

School religiosity climate juga diwujudkan dalam hubungan social, baik internal maupun antarguru, siswa, karyawan, dan dengan kepala sekolah. Diawali dengan kepedulian kepala sekolah, dan wali-wali kelas, mempersiapkan untuk melakukan puja tri sandya sebelum belajar ke dalam kelas.

Hubungan komunikasi antara kepala sekolah dan guru-guru serta siswa harus seimbang, harmonis, dan selalu berdasarkan keadilan. Apabila budaya komunikasi dan hubungan yang erat sudah dilaksanakan maka muncul rasa tanggung jawab dan disipli yang tinggi. Membangun kultur seprofesi dalam organisasi seperti; membentuk musyawarah guru mata pelajaran (MGMP), kelompok kerja guru (KKG), dan supervisi pendidikan.

3. Membangun komunikasi secara intensif.

Intervice training (pelatihan intervensi) dalam meningkatkan profesionalisme guru yang berbasis nilai religius, biasanya mengedepankan pembentukan kepribadian, penanaman nilai-nilai keimanan, keiklasan dalam diri. Dalam perspektif ini, agama yang diterima melalui pengetahuan dan pengalaman atau apa yang di aplikasikan secara aktual maupun yang dihayati melalui pengalaman rohani, masuk kedalam struktur kepribadian seseorang.

4. Budaya bersikap berpenampilan, dan berakhlak mulia.

Pendidikan merupakan transfer budaya, sementara kebudayaan masyarakat mengandung unsur-unsur; 1) akhlak atau etika, 2) estetika, 3) ilmu pengetahuan, teknologi, dan sedangkan sebagaian besar tingkah laku manusia terbentuk melalui proses pembiasaan., prilaku yang wajib dilakukan guru ialah sopan santun, berjiwa besar, dan kesabaran.

\section{Internalisasi Nilai-Nilai Kerja Guru Agama Berbasis Budaya Religius.}

Dalam manajemen pendidikan, berbagai pihak yang terlibat di dalamnya diatur oleh aturan-aturan baik formal maupun informal. Aturan formal digunakan utnuk 
mengelola kerja, komponen-komponen yang ada agar mereka dapat bekerja dengan lancar, efisien, dan efektif. Aturan informal menyangkut nilai agama atau kultur luhur yang mereka yakini selalu diterapkan dalam kehidupan sehingga menjadi bagian kehidupan mereka, yang secara sengaja atau tidak banyak mempengaruhi tingkah laku mereka dalam melaksanakan tugasnya disekolah.

Salah satu upaya untuk memotivasi dan mengefektifkan sumber daya manusia dalam mengelola pendidikan dapat dilakukan melalui internalisasi nilai-nilai pada suasana kerja dan suasana pergaulan sehari-hari. Upaya ini dilakukan karena lembaga pendidikan Hindu (pasraman), nilai keagamaan sering kali menjadi penentu keberhasilan pengelolaan lembaga pendidikan terutama dalam rangka menjalankan misi dan meraih visi masa depan.

Menurut Solaiman (1988:68) salah satu yang mendorong seseorang bekerja dalam masyarakat religius ialah nilai yang melandasi hidupnya, khususnya nilai religius yang merupakan sumber pertama dan utama bagi para penganutnya. Dari segi rleligius mereka menyebarkan nilai-nilai untuk diaktualisasikan dalam kehidupan sehari-hari. Bahkan di Indonesia nilai agama mempunyai arti/posisi dan peranan/ fungsi yang sangat penting dalam mewujudkan manusia seutuhnya.

\section{SIMPULAN}

Kebertahan budaya sekolah, guru merupakan kunci utama, dan guru harus mampu menunjukkan kinerja maksimal di dalam menjalankan tugas dan fungsinya sebagai pendidik, pengajar, dan pelatih. Budaya sekolah bukan merupakan fenomena baru, melainkan penggalian kembali hal-hal penting tentang budaya sebagai faktor pertimbangan terbaik di sekolah. Peranan kepala sekolah didalam penciptaan dan pelanjutan suatu budaya sekolah adalah mengembangkan fokus berdasarkan perbuatnperbuatan kepala sekolah di masa yang akan datang melalui sesuatu yang penting dan aktivitas-aktivitas sebagai manejerial.

Peningkatan kinerja guru mengajar merupakan suatu usaha untuk meningkatkan kualitas hasil pendidik. Usaha tersebut dilakukan karena masalah-masalah yang berkaitan dengan tenaga guru dan pegawai di sekolah biasanya meliputi kurang memadainya kualifikasi dan kompetensi tenaga pengajar, rendahnya etos kerja, kurangnya penghrgaan masyarakat terhadap komitmen tenaga pengajar, dan kurangnya penghargaan masyarakat terhadap profesi tenaga guru.

Membangun sebuah budaya religius merupakan, kinerja guru agama Hindu dan warga sekolah, sebagai gerakkan yang dilakukan oleh agama dari proses interaksi manusia dengan sebuah ajaran yang telah diyakini, sehingga hubungan budaya dengan agama merupakan integritas seseorang atau kelompok.

Budaya religius adalah perilaku akhlak kerja yang terjadi karena internalisasi keyakinan nilai kerja yang berasal dari akhlak mulia, baik nilai spiritual-keagmaan IMTAQ, IPTEK, adat istiadat, hukum maupun etika yang ditumbuhkembangkan sebagai gaerah (etos kerja).

Program-program yang diterapkan oleh kepala sekolah dalam meningkatkan professional guru berbasis religius sebagai berikut. 1). mengembangkan budaya keteladaan dan kedisiplinan, 2). membangun komunikasi secara intensif, 3). Membangun komunikasi secara intensif, dan 4). budaya bersikap berpenampilan, dan berakhlak mulia.. 


\section{DAFTAR PUSTAKA}

Agung, Iskandar, 2013. Pengembangan Pola Kerja Harmonis dan Sinergi antara Guru, Kepala Sekolah, dan pengawas. Jakarta:Bestari Buana Murni.

Agung, Iskandar, 2012. Menghasilkan Guru Kompetensi dan Profesional. Jakrta: Bee Media.

Ahmadi, Abu dan Nur Uhbyati, 2001. Ilmu Pendidikan. Jakarta: Rineka Cipta.

Amtu, Onisimus, 2011. Manajemen Pendidikan di Era Otonomi Daerah. Bandung: Alfabeta.

Dakir, 2004. Perencanaan dan Pengembangan Kurikulum. Jakarta: Reneka Cipta.

Daryanto, 2015. Pengelolaan Budaya religius. Yogya: Gava Media.

Dediknas, 2003. UU RI No.20 Tahun 2003 tentang Sisdiknas: Jakarta.

Fathur, A. 2011.Pembinaan Guru Pascasertifikasi, Perlukah?. Dalam http//father. dosenunimus.ac.id, diakses 12 Agustus 2014(dalam kompri, 2015: 335

Fattah, Nanang, 2000. Ekonomi dan Pembelajaran Pendidikan. Bandung: Remaja Rosdakarya.

2006. Landasan Manajemen pendidikan. Bandung: Remaja Rosdakarya.

Gemes, Faustino Cardoso. 2003. Manajemen SDM. Yogyakarta: Andi.

Hamalik, Oemar, 2004. Proses Belajar Mengajar. Jakarta: Bumi Aksara.
Jasmani dan Syaiful Mustofa. 2013. Supervisi Pendidikan.Yogyakarta: Ar-Ruzz Media.

Kahmad, Dadng, 2002. Sosiologi Agama. Bandung: Remaja Rosdakarya.

Kompri, 2015. Manajemen Pendidikan. Yoyakarta: AR-Ruzz Media. 